\title{
Heterogeneity of Human Lactoferrin Due to Differences in Sialic Acid Content
}

\author{
Devora R. Wolfson ${ }^{[32]}$ And John B. Robbins \\ Department of Pediatrics, Albert Einstein College of Medicine, Bronx, New York, USA
}

\section{Extract}

Differences in sialic acid content and not genetic polymorphism determine the observed electrophoretic heterogeneity of human lactoferrin, the iron-binding protein of external secretions. Lactoferrin molecules have at least one to four sialic acid residues. The asialo derivative is electrophoretically homogeneous.

\section{Speculation}

As with other nonhuman iron-binding proteins from various species, human lactoferrin from several secretions was shown to have varying sialic acid content. A regulatory role of sialic acid in the regulation of secretion and function of lactoferrin is postulated.

\section{Introduction}

Lactoferrin, the iron-binding protein of exocrine tissue secretions, was isolated from human milk and duodenal fluid. This purified lactoferrin was observed to be electrophoretically heterogeneous. The basis for this charge heterogeneity was studied and found to be due to differing sialic acid content of protein molecules.

\section{Materials and Methods}

A procelure for the isolation of various forms of lactoferrin with protein of different net charges was devised utilizing cation exchange chromatography (CMC) [26] followed by Sephadex G-100 gel filtration. In a representative experiment, $500 \mathrm{ml}$ human milk serum [27] obtained from pooled frozen milk from three donors contained $680 \mathrm{mg}$ lactoferrin [10]. The milk serum was dialyzed against $0.05 \mathrm{~m}$ acetate buffer, $\mathrm{pH} 5.3$, and adsorbed to a $2.5-\mathrm{cm}$ by $50-\mathrm{cm}$ CMC column equilibrated with the same buffer maintained at $4^{\circ}$. The effluent was monitored for protein by absorbance at $280 \mathrm{~m}_{\mu}$ and for lactoferrin using anticolostral protein and antilactoferrin antisera. Ten column volumes of the initial buffer were allowed to flow through the CMC. After two protein peaks were obtained which did not contain lactoferrin, an ionic gradient of 0.1-0.2 $\mathrm{m} \mathrm{NaCl}$ in the acetate buffer was applied for elution. A peak containing IgA was eluted, followed by a long low protein peak (approximately 5 column volumes) containing lactoferrin. To obtain lactoferrin molecules of different net charges the first half of the peak containing lactoferrin was pooled and designated fraction $A$, and the second half, fraction B. After completion of the gradient, lactoferrin, designated $C$, was sharply eluted with $1.0 \mathrm{M} \mathrm{NaCl}$. The three lactoferrin fractions were separately purified using a $2.5-\mathrm{cm}$ by 100 cm Sephadex G-100 gel filtration column. The conditions of this chromatography were: $(1)$ the solvent was 1.0 м NaCl, 0.01 м Tris-HCl, 0.001 м EDTA, pH 8.0; (2) temperature was $4^{\circ}$; (3) flow rate was $10 \mathrm{ml} / \mathrm{hr} ;(7)$ fraction size was $5.0 \mathrm{ml}$. The final product yielded 35 $\mathrm{mg}$ fraction $A, 250 \mathrm{mg}$ fraction $B$, and $316 \mathrm{mg}$ fraction $C$, which accounted for $88 \%$ of the lactoferrin present in the original milk sample.

The molecular weight of lactoferrin was determined 
by the method described by Whitaker [24]. A $2.5-\mathrm{cm}$ by $100-\mathrm{cm}$ column of Sephadex G-200 was calibrated with $1.0-\mathrm{ml}$ samples of purified equine cytochrome $c$, human serum albumin, and rabbit IgG globulin containing $5.0 \mathrm{mg} / \mathrm{ml}$. The solvent was $0.1 \mathrm{M} \mathrm{NaCl}, 0.01 \mathrm{Mr}$ Tris-HCl, 0.001 m EDTA (pH 7.0), the flow rate was $10.0 \mathrm{ml} / \mathrm{hr}$, and the temperature was $4^{\circ}$. With this method, the molecular weight of lactoferrin was found to be 96,000 .

\section{Results}

Purity and antigenic identity of the lactoferrin preparations were demonstrated by a single precipitin line following immunoelectrophoresis (Fig. $1 A$ ) and immunodiffusion (Fig. 1B) with goat antilhuman colostral protein antiserum. The purity was further confirmed when a goat and a rabbit immunized with purified lactoferrin in Freund's adjuvant produced antisera giving single precipitin bands with human colostrum.

Immunoelectrophoresis (Fig. $1 A$ ) showed that lactoferrin $A$ migrated fastest toward the anode. Fraction $C$, eluted last from the column, had the slowest migration, and fraction $B$ had intermediate mobility. Polyacrylamide gel electrophoresis [4] resolved each fraction into two to threc separate protein bands (Fig. $1 C$ ). The fastest moving bands, called 1,2 , and 3 , were found in fraction $A$. These findings were confirmed by vertical starch gel electrophoresis [17, 18]. Attempts to fractionate the lactoferrin into preparations yielding single bands by polyacrylamide gel electrophoresis were unsuccessful. The sialic acid content [22] of the three lactoferrin fractions was measured using neuraminic acid, clried over $\mathrm{P}_{2} \mathrm{O}_{5}$ at $0.5 \mathrm{~mm} \mathrm{Hg}$ pressure at $4^{\circ}$ to
Table I. Sialic acid content of human milk lactoferrin 1

\begin{tabular}{lcccc}
\hline \multicolumn{1}{c}{ Sample } & Pooled milk & Donor $J S$ & Donor $E K$ & Donor $B M$ \\
\hline Fraction $A$ & 4.09 & 4.67 & 3.92 & 4.01 \\
Fraction $B$ & 3.38 & 3.75 & 3.75 & 3.80 \\
Fraction $C$ & 2.31 & 2.47 & 2.67 & 2.20 \\
$A+B+C$ at pH 4.6 & 3.50 & & & \\
$A+B+C$ at pH 4.6 & 3.50 & & & \\
$A+B+C$ at pH 8.0 & 3.76 & & & \\
$A+B+C$ at pH 8.0 & 3.71 & & &
\end{tabular}

1 The sialic acid content of pooled and individual samples of fractionated milk lactoferrin was analyzed by the method of Warren [22]. The results are expressed as micromoles of sialic acid per micromole of lactoferrin, assuming the molecular weight of the protein to be 96,000 [24].

a constant weight, as a standard. The most negatively charged lactoferrin, $A$ (Table I), contained $4.09 \mu \mathrm{Mr}$ sialic acid, fraction $B$ contained $3.38 \mu \mathrm{M}$ sialic acid, and fraction $C$ contained $2.31 \mu \mathrm{M}$ sialic acid $/ \mu \mathrm{M}$ lactoferrin.

To ascertain that the differing sialic acid values were not due to genetic variations, lactoferrins $A, B$, and $C$ from three individuals, $J S, E K$, and $B M$, were isolated. All of these lactoferrin samples demonstrated similar electrophoretic mobilities and sialic acid content as pooled milk (Table I).

To verify that the heterogeneity was not a result of the isolation procedure, lactoferrin was obtained containing all of the forms by DEAE-cellulose chromatography and gel filtration (Sephadex G-100) of whole human milk [15] that had not been subjected to the isoelectric precipitation of casein. Following dialysis of whole milk, a sample containing $100 \mathrm{ml}$ was applied to DEAE column (5 by $50 \mathrm{~cm}$ ) [28] at $0.001 \mathrm{~m}$ potassium
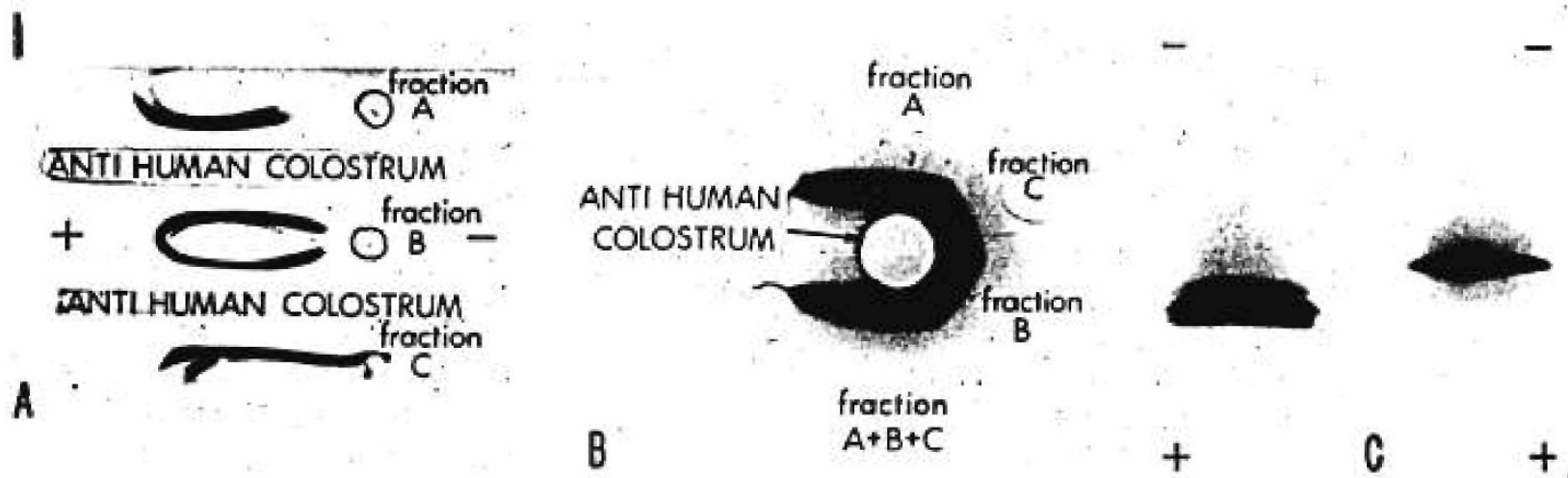

Fig. 1. Analysis of lactoferrin fractions from pooled human milk. A: Immunoelectrophoresis of the three fractions developed with goat antihuman colostral protein serum. $B$ : Immunodiffusion of the three fractions $(2.0 \mathrm{mg} / \mathrm{ml}$ protein solutions) showing antigenic identity. $C$ : Polyacrylamide gel electrophoresis of lactoferrin fraction $B(l e f t)$ and fraction $B$ after neuraminidase treatment (right). At least three proteins are observed in the native form. Following neuraminidase treatment only one protein band with a slower anodal mobility than any untreated protein was observed. 
phosphate, 0.001 м EDTA, pH 7.5, at $4^{\circ}$ and eluted with 0.05 м $\mathrm{NaCl}$. The lactoferrin-containing fractions were further purified by gel filtration using Sephadex G.100 (vide supra). Aliquots of this lactoferrin were dialyzed at $\mathrm{pH} 4.6$ and $\mathrm{pH} 8.0$ for $48 \mathrm{hr}$. The sialic acid content of these two preparations were almost iclentical (Table I).

To ascertain whether iron content affected the heterogeneity, lactoferrin was dialyzed at $\mathrm{pH} 2.0$ for $12 \mathrm{hr}$ at $4^{\circ}[3,6]$. The resulting iron-free preparation showed the same heterogeneity.

The asialo derivatives of the three lactoferrin fractions were prepared by incubating $0.5 \mathrm{mg}$ of each fraction with $0.1 \mathrm{ml}$ neuraminidase containing 50 units [29] in a dialysis sac with $0.01 \mathrm{M} \mathrm{CaCl}_{2}-0.05$ M $\mathrm{NaCH}_{3} \mathrm{O}_{2}, \mathrm{pH} 5.2$ [1], as the solvent and outer fluid for $17 \mathrm{hr}$ at $37^{\circ}$. These derivatives yielded single bands of protein with identical mobility by polyacrylamide gel electrophoresis (Fig. $1 C$ ), slower than the slowest naturally occurring lactoferrin. Therefore, it may be concluded that all lactoferrin molecules contain at least one sialic acid resiclue and that there is no genetic polymorphism detectable by these techniques.

Lactoferrin fractions $A, B$, and $C$ were isolated by this technique from the duodenal fluid of one human. Polyacrylamide gel electrophoresis, immunoelectrophoresis, and immunodiffusion studies revealed the same heterogeneity, relative quantities, and antigenic identity of the three fractions as milk lactoferrin.

Pooled and three individual saliva samples gave heterogeneous precipitation bands by immunoelectrophoresis with antilactoferrin and anticolostral antisera, identical with those observed in milk lactoferrin.

\section{Discussion}

Difference in sialic acid content characterizes the ironbinding proteins of many vertebrates $[1,25]$. In the rabbit [1], milk and serum transferrins have identical protein moieties and are electrophoretically heterogeneous. Neuraminidase treatment yields an electrophoretically homogeneous protein. In the domestic fowl [25], the iron-binding proteins conalbumin and serum transferrin have three electrophoretic forms. Stepwise reduction of the mobilities of these three bands is obtained by neuraminidlase. In lumans, serum transferrin [14] is homogeneous but can be resolved into four electrophoretically slower components by neuraminidase treatment. In human cord serum, these slower bands are present, probably due to an immature enzyme mechanism in fetal liver for the stepwise addition of sialic acid to fetal transferrin. Human cere- brospinal fluid has two electrophoretic varieties corresponding to the slowest and fastest transferrin. Neuraminiclase treatment of polymorphic variants of human transferrin provides evidence that sialic acid is not involved in this genetic variation. Direct measurement of sialic acid of these electrophoretic variants of ironbincling proteins, however, has not been previously reported. We have found lactoferrin to be similar to the iron-binding proteins previously studied in that differences in the heterogeneity can be explained by differences in sialic content only.

Human lactoferrin was first identified in $1960[3,5$, $6,13]$ and its physical and chemical properties were characterized. Lactoferrin is found in external secretions such as bile [16], saliva, semen, bronchial secretions, and milk, but not in human serum including the sera of lactating females [3]. There is no relation or identity among peptide sequences between human lactoferrin and transferrin $[3,6,19]$. Fluorescent antibody studies suggest that lactoferrin is synthesized in bronchial and salivary glands [11, 21]. In the rabbit [8], there is no transport of labeled serum transferrin to milk [7]. Other evidence suggests that lactoferrin may also be an intracellular constituent [12] of circulating leukocytes.

Sialic acid has widespread distribution in the animal organism [23] but its biologic function for proteins is unknown. It does not appear to be related to ironbinding by lactoferrin $[3,14,16]$, or the resistance of lactoferrins to intestinal protease [19].

Since the carbohydrate moiety has been implicated in the transport of one type of glycoprotein (immunoglobulins) across the cell membrane [20], and since all lactoferrin contains at least one sialic acid residue, a possible role for sialic acid may be in the transport of this protein across the cell membrane. The occurrence of lactoferrin in heterogeneous form suggests the presence of an enzyme mechanism in human secretory glands for the stepwise addlition of sialic acid to a protein molecule. Such an enzyme mechanism has been demonstrated in mammalian and human mammary tissue $[2,9]$. Since sialic acid is a terminal residue of the carbohydrate chain of many glycoproteins, it may be necessary for extracellular transport of these proteins.

\section{References and Notes}

1. Baker, E., Shaw, D. C., and Morgan, E. H.: Isolation and characterization of rabbit serum and milk transferrins. Evidence for difference in sialic acid content only. Biochemistry, 7: 1371 (1968). 
2. Bartholomew, B., Jourdian, G. W., AND Roseman, B.: Soluble sialyl-transferases from colostrum. Int. Congr. Biochem. Abstr., 6: 503 (1964).

3. BLANC, B., AND Isliker, H.: Isolement et caracterisation de la protéins rouge sideraphile du lait maternal et la lactotransferrine. Bull. Soc. Chim. Biol., \$3: 929 (1961).

4. Clarke, J. T.: Simplified "disc" (polyacrylamide gel) electrophoresis. Ann. N. Y. Acad. Sci., 121: 428 (1964).

5. Grüttner, R., Schüffer, K. H., and Schröter, W.: Zur Reindarstellung eines cisenbindenden Proteins in der Frauenmilch. Klin. Wschr., 38: 1162 (1960).

6. JohnNSON, B.: Isolation of an iron-containing red protein from human milk. Acta Chem. Scand., 14: 510 (1960).

7. Jokdal, R.: Undersogelser over transferrin Stofskiltet (Illemann, Copenhagen, 1963).

8. Jordan, S. M., Kaldor, I., and Morgan, E. H.: Milk and serum iron and iron-binding capacity in the rabbit. Nature, 21: 76 (1967).

9. Jourdin, G. W., Carlson, D. M., and Roseman, S.: The enzymatic synthesis of sialyl-lactose. Biochem. Biophys. Res. Commun., 10: 352 (1963).

10. Mancini, G., Carbonara, A. O., and Heremans, J. F.: Immunochemical quantitation of antigens by single radial immunodiffusion. Immunochemistry, 2: 235 (1965).

11. Masson, P., Heremans, J. F., and Prignet, J.: Immuno histochemical localization of the iron-binding protein lactoferrin in human bronchial glands. Experientia, 21: 604 (1965).

12. Masson, P. L., Heremans, J. F., and Schonne, E.: Lactoferrin, an iron-binding protein in neutrophilic leukocytes. J. Exp. Med., 130: 643 (1969).

13. Montreuil, J., ANd Muli.et, S.: Isolement d'une lactosiderophiline du lait de femme. C. R. Acad. Sci. (Paris), 250: 1736 (1960).

14. Montreuth, J., Tonneldit, J., and Mullet, S.: Preparation et proprietes de la lactosiderophiline (lactotransferrin) du lait de femme. Biochim. Biophys. Acta, 45: 413 (1960).

15. Roвmins, J. B.: Unpublished observation.

16. Schultze, H. E., AND Heremans, J. F.: Molecular Biology of Human Proteins, pp. 806, 819, 823, 833 (American Elsevier, New York, 1966).

17. SMmpies, O.: Zone electrophoresis in starch gels: group variations in the serum proteins of normal human adults. Biochem. J., 61: 629 (1955).

18. Sintuifs, O.: An improved procedure for starch-gel electro- phoresis: further variations in the serum proteins of normal individuals. Biochem. J., 71: 585 (1959).

19. Si'ik, G., AND MontreuiL, J.: Etudes comparatives de la structure de la transferrine et de la lactotransferrine humaines "finger printing" des hydrolysate proteasiques des deux glycoproteides. C. R. Seances Soc. Biol. Filiales, 160: 94 (1966).

20. Swenson, R. M., ANd Kern, M.: The synthesis and secretion of gammaglobulin by lymph node cells. III. The slow acquisition of the carbohydrate moiety of gammaglobulin and its relationship to secretion. Proc. Nat. Acad. Sci. U. S. A., 59: $546(1968)$.

21. Tourville, D. R., Adler, R. H., Bienenstock, J., and Tomasi, T. B., JR.: The human secretory immunoglobulin system: immunohistological localization of gamma-A, secretory "piece," and lactoferrin in human tissue. J. Exp. Med., 129: 411 (1969).

22. WArren, L.: The thiobarbituric acid assay of sialic acid. J. Biol. Chem., 23t: 1971 (1959).

23. Werner, I., and Odin, L.: On the presence of sialic acid in certain glycoproteins and in gangliosides. Acta Soc. Med. Upsal., 57: 230 (1952).

24. Whittaker, J. R.: Determination of molecular weights of proteins by gel filtration in Sephadex. Anal. Chem., 35: 1950 (1963).

25. Whlians, J.: A comparision of conalbumin and transferrin in the domestic fowl. Biochem. J., 83: 355 (1962).

26. Carboxymethylcellulose, Whatman CM 32, H. Reeve Angel and Company, Clifton, N. J.

27. Obtained by isoelectric precipitation of casein, $\mathrm{pH} 4.6$, in acetate buffer.

28. DEAE-cellulose, H. Reeve Angel and Company, Clifton, N. J.

29. Neuraminidase, from Clostridum perfringens type VI. Chromatographically purified, Sigma Chemical Company, St. Louis, Mo.

30. DR. Wolfson was supported in part by National Institutes of Health Training Grant no. HD-0078.

31. 1). RoвBins was supported in part by National Institute of Allergy and Infectious Diseases Training Grant no. AI 811003 and Carcer Development Award no. K03 HD 22856-07, from the National Institutes of Health.

32. Requests for reprints should be addressed to: D. R. Wotfson, 1)epartment of Pediatrics, Albert Einstein College of Medicine, 1300 Morris Park Avenue, Bronx, N. Y. 10461 (USA).

33. Accepted for publication December 4,1970 . 